\title{
Performance of explicit approximations of the coefficient of head loss for pressurized conduits
}

\author{
Bruna D. Pimenta ${ }^{1}$, Adroaldo D. Robaina ${ }^{1}$, Marcia X. Peiter ${ }^{1}$, \\ Wellington Mezzomo ${ }^{1}$, Jardel H. Kirchner ${ }^{1} \&$ Luis H. B. Ben ${ }^{1}$ \\ ${ }^{1}$ Universidade Federal de Santa Maria/Centro de Ciências Rurais/Departamento de Engenharia Agrícola. Santa Maria, RS. E-mail: brunadpimenta@gmail.com \\ (Corresponding author) - ORCID: 0000-0003-2895-9419; diasrobaina@gmail.com - ORCID: 0000-0001-6553-7878; mpeiter@gmail.com - ORCID: \\ 0000-0001-8945-5412; wmezzomo@hotmail.com - ORCID: 0000-0002-1169-0620; jardelkirchner@hotmail.com - ORCID: 0000-0003-2126-4593; \\ luishumbertoben@gmail.com - ORCID: 0000-0003-4284-3789
}

Key words:

head loss

Darcy-Weisbach

turbulent flow regime

performance index

\begin{abstract}
A B S T R A C T
One of the parameters involved in the design of pressurized hydraulic systems is the pressure drop in the pipes. The verification of the pressure drop can be performed through the DarcyWeisbach formulation, which considers a coefficient of head loss (f) that can be estimated by the implicit Colebrook-White equation. However, for this determination, it is necessary to use numerical methods or the Moody diagram. Because of this, numerous explicit approaches have been proposed to overcome such limitation. In this sense, the objective of this study was to analyze the explicit approximations of the f for pressurized conduits in comparison to the Colebrook-White formulation, determining the most precise ones so that they can be used as an alternative solution that is valid for the turbulent flow regime. Twenty nine explicit equations found in the literature were analysed, determining the $f$ through the Reynolds number in the range of $4 \times 10^{3} \leq \mathrm{Re} \leq 10^{8}$ and a relative roughness $(\mathrm{E} / \mathrm{D})$ of $10^{-6} \leq \mathcal{E} / \mathrm{D} \leq 5 \times 10^{-2}$, and obtaining 160 points for each equation. The performance index and relative error of the formulations were analyzed in relation to the Colebrook-White equation. Considering the equations analyzed, we found seven that presented excellent performance and high precision, highlighting the formulation of Offor \& Alabi, which can be used as an alternative to the Colebrook-White standard equation.
\end{abstract}

\section{Palavras-chave:} perda de carga Darcy-Weisbach regime de fluxo turbulento índice de desempenho

\section{Desempenho de aproximações explícitas do coeficiente de perda de carga para condutos pressurizados}

\section{R E S U M O}

Um dos parâmetros envolvido no dimensionamento de sistemas hidráulicos pressurizados é a perda de carga das tubulações. Essa verificação pode ser realizada através da formulação de Darcy-Weisbach, que considera um coeficiente de perda de carga (f) que pode ser mensurado pela equação implícita de Colebrook-White. No entanto, para essa determinação é necessário utilizar métodos numéricos ou o diagrama de Moody. Devido a isso, numerosas aproximações explícitas são propostas para superar essa limitação. Nesse sentido, o objetivo desse trabalho é analisar as aproximações explícitas do f para condutos pressurizados em comparação a formulação de Colebrook-White, determinando as mais precisas para que possam ser uma solução alternativa, válidas para o regime de fluxo turbulento. Foram analisadas 29 equações explícitas encontradas na literatura, determinando o f através do número de Reynolds (Re) na faixa de $4 \times 10^{3} \leq \mathrm{Re} \leq 10^{8}$ e rugosidade relativa (E/D) de $10^{-6} \leq \mathcal{E} / \mathrm{D} \leq 5 \times 10^{-2}$, obtendo 160 pontos para cada equação. O índice de desempenho e o erro relativo das formulações foram analisados em relação a equação de ColebrookWhite. Considerando as equações analisadas, sete apresentaram excelente desempenho e alta precisão, destacando a formulação de Offor \& Alabi, a qual pode ser utilizada como alternativa à equação padrão de Colebrook-White. 


\section{INTRODUCTION}

The estimation of head loss in pressurized conduits is a significant problem in optimization studies, hydraulic analysis of ducts, and water distribution systems (Bardestani et al., 2017).

The Colebrook-White (1937) (CW) equation has been considered as the most accurate approximation for the determination of the head loss coefficient (f) and has been used as a reference standard; it uses the Reynolds number $(\mathrm{Re})$ and the relative roughness of the pipe (E/D) (Heydari et al., 2015; Brkić \& Ćojbašić, 2016) and is valid for a wide range of applicability: $2 \times 10^{3}<\mathrm{Re}<10^{8}$ and $0 \leq \mathcal{E} / \mathrm{D} \geq 0.05$. However, it is implicit in relation to $\mathrm{f}$ and requires an iterative process for the solution (Brkić, 2016; Brkić \& Ćojbašić, 2017).

Several researchers have sought to find explicit equations that could be used as alternatives to the CW equation (Assefa \& Kaushal, 2015; Mikata \& Walczak, 2015). According to Brkić \& Ćojbašić (2017), explicit approximations give a relatively good prediction of the $f$ and can accurately reproduce the CW equation and the Moody (1944) diagram. In some of these explicit equations, their relative error is so small that they can be used directly instead of the CW equation (Çoban, 2012).

Therefore, the objective of this research was to analyze some explicit approximations of the pressure loss coefficient for pressurized conduits, determining the most accurate ones so that they can be used as an alternative to the CW formulation.

\section{Material ANd Methods}

The determination of the f of all equations were performed using a Microsoft Excel worksheet, with Re values in the range of $4 \times 10^{3} \leq \operatorname{Re} \leq 10^{8}$ and $\mathrm{E} / \mathrm{D}$ of $10^{-6} \leq \mathrm{E} / \mathrm{D} \leq 5 \times 10^{-2}$, and 160 points of data for each approximation analyzed were obtained. The CW formulation, Eq. 1, can be identified by:

$$
\frac{1}{\sqrt{\mathrm{f}}}=-2 \log \left(\frac{\varepsilon}{3.7 \mathrm{D}}+\frac{2.51}{\operatorname{Re} \sqrt{\mathrm{f}}}\right)
$$

Table 1. Explicit approximations for the determination of the head loss coefficient (f), with their respective authors, years of publication, and application ranges

\begin{tabular}{|c|c|c|c|}
\hline Authors (Year) & Explicit equation of the $f$ & Applicable ranges & $\begin{array}{l}\text { Equation } \\
\text { number }\end{array}$ \\
\hline Moody (1947) & $\mathrm{f}=0.0055\left[1+\left(2 \times 10^{4} \frac{\varepsilon}{\mathrm{D}}+\frac{10^{6}}{\mathrm{Re}}\right)^{1 / 3}\right]$ & $\begin{array}{c}4 \times 10^{3} \leq \mathrm{Re} \leq 10^{8} \\
0 \leq \varepsilon / D \leq 10^{-2}\end{array}$ & (2) \\
\hline Wood (1966) & $\mathrm{f}=0.094\left(\frac{\varepsilon}{\mathrm{D}}\right)^{0.225}+0.53\left(\frac{\varepsilon}{\mathrm{D}}\right)+88\left(\frac{\varepsilon}{\mathrm{D}}\right)^{0.44} \mathrm{Re}^{-\left[1,62\left(\frac{\varepsilon}{\mathrm{D}}\right)^{0.134}\right]}$ & $\begin{array}{l}4 \times 10^{3} \leq R e \leq 5 \times 10^{7} \\
10^{-5} \leq \varepsilon / D \leq 4 \times 10^{-2}\end{array}$ & (3) \\
\hline Churchill (1973) & $\frac{1}{\sqrt{\mathrm{f}}}=-2 \log \left[\frac{\varepsilon}{3.71 \mathrm{D}}+\left(\frac{7}{\mathrm{Re}}\right)^{0.9}\right]$ & Not specified & (4) \\
\hline Eck (1973) & $\frac{1}{\sqrt{f}}=-2 \log \left(\frac{\varepsilon}{3.71 D}+\frac{15}{R e}\right)$ & $0 \leq \varepsilon / D \leq 10^{-2}$ & (5) \\
\hline Jain (1976) & $\frac{1}{\sqrt{f}}=-2 \log \left[\frac{\varepsilon}{3.715 D}+\left(\frac{6.943}{\operatorname{Re}}\right)^{0.9}\right]$ & $5 \times 10^{3} \leq \mathrm{Re} \leq 10^{7}$ & (6) \\
\hline $\begin{array}{l}\text { Swamee \& Jain } \\
\quad(1976)\end{array}$ & $\frac{1}{\sqrt{\mathrm{f}}}=-2 \log \left(\frac{\varepsilon}{3.7 \mathrm{D}}+\frac{5.74}{\mathrm{Re}^{0.9}}\right)$ & $\begin{array}{l}5 \times 10^{3} \leq \mathrm{Re} \leq 10^{8} \\
10^{-6} \leq \varepsilon / \mathrm{D} \leq 5 \times 10^{-2}\end{array}$ & (7) \\
\hline Chen (1979) & $\frac{1}{\sqrt{\mathrm{f}}}=-2 \log \left[\frac{\varepsilon}{3.7065 \mathrm{D}}-\frac{5.0452}{\operatorname{Re}} \log \left(\frac{1}{2.8257}\left(\frac{\varepsilon}{\mathrm{D}}\right)^{1.1098}+\frac{5.8506}{\mathrm{Re}^{0.8981}}\right)\right]$ & $\begin{array}{l}4 \times 10^{3} \leq \mathrm{Re} \leq 4 \times 10^{8} \\
10^{-7} \leq \varepsilon / D \leq 5 \times 10^{-2}\end{array}$ & (8) \\
\hline Round (1980) & $\frac{1}{\sqrt{\mathrm{f}}}=1.8 \log \left[\frac{\operatorname{Re}}{0.135 \operatorname{Re}\left(\frac{\varepsilon}{D}\right)+6.5}\right]$ & $\begin{array}{l}4 \times 10^{3} \leq R e \leq 10^{8} \\
0 \leq \varepsilon / D \leq 5 \times 10^{-2}\end{array}$ & (9) \\
\hline Shacham (1980) & $\frac{1}{\sqrt{\mathrm{f}}}=-2 \log \left[\frac{\varepsilon}{3.7 \mathrm{D}}-\frac{5.02}{\operatorname{Re}} \log \left(\frac{\varepsilon}{3.7 \mathrm{D}}+\frac{14.5}{\mathrm{Re}}\right)\right]$ & $4 \times 10^{3} \leq \mathrm{Re} \leq 4 \times 10^{8}$ & (10) \\
\hline Barr (1981) & $\frac{1}{\sqrt{\mathrm{f}}}=-2 \log \left\{\frac{\varepsilon}{3.7 \mathrm{D}}+\frac{4.518 \log \left(\frac{\mathrm{Re}}{7}\right)}{\operatorname{Re}\left[1+\frac{\operatorname{Re}^{0.52}}{29}\left(\frac{\varepsilon}{\mathrm{D}}\right)^{0.7}\right]}\right\}$ & Not specified & (11) \\
\hline $\begin{array}{c}\text { Zigrang \& } \\
\text { Sylvester (1982) }\end{array}$ & $\frac{1}{\sqrt{f}}=-2 \log \left\{\frac{\varepsilon}{3.7 D}-\frac{5.02}{R e} \log \left[\frac{\varepsilon}{3.7 D}-\frac{5.02}{R e} \log \left(\frac{\varepsilon}{3.7 D}+\frac{13}{R e}\right)\right]\right\}$ & $\begin{array}{c}4 \times 10^{3} \leq R e \leq 10^{8} \\
4 \times 10^{-5} \leq \varepsilon / D \leq 5 \times 10^{-2}\end{array}$ & (12) \\
\hline Haaland (1983) & $\frac{1}{\sqrt{\mathrm{f}}}=-1.8 \log \left[\left(\frac{\varepsilon}{3.7 \mathrm{D}}\right)^{1.11}+\frac{6.9}{\mathrm{Re}}\right]$ & $\begin{array}{l}4 \times 10^{3} \leq R e \leq 10^{8} \\
10^{-6} \leq \varepsilon / D \leq 5 \times 10^{-2}\end{array}$ & (13) \\
\hline Tsal (1989) & $\begin{array}{c}A=0.11\left(\frac{68}{\operatorname{Re}}+\frac{\varepsilon}{D}\right)^{0.25} \\
\text { If } A \geq 0.018 \text { than } f=A \\
\text { If } A<0.018 \text { than } f=0.0028+0.85 A\end{array}$ & $\begin{array}{l}4 \times 10^{3} \leq \operatorname{Re} \leq 10^{8} \\
0 \leq \varepsilon / D \leq 5 \times 10^{-2}\end{array}$ & (14) \\
\hline Robaina (1992) & $\frac{1}{\sqrt{f}}=-2 \log \left(0.27 \frac{\varepsilon}{D}+\frac{5.62}{\operatorname{Re}^{0.9}}\right)$ & $\begin{aligned} 4 \times 10^{3} & \leq \operatorname{Re} \leq 4 \times 10^{7} \\
10^{-5} & \leq \varepsilon / D \leq 10^{-2}\end{aligned}$ & (15) \\
\hline Manadilli (1997) & $\frac{1}{\sqrt{f}}=-2 \log \left(\frac{\varepsilon}{D}+\frac{95}{\operatorname{Re}^{0.983}}+\frac{96.82}{R e}\right)$ & $\begin{array}{l}5.235 \times 10^{3} \leq \mathrm{Re} \leq 10^{8} \\
0 \leq \varepsilon / \mathrm{D} \leq 5 \times 10^{-2}\end{array}$ & (16) \\
\hline $\begin{array}{l}\text { Sousa et al. } \\
(1999)\end{array}$ & $\frac{1}{\sqrt{f}}=-2 \log \left[\frac{\varepsilon}{3.7 \mathrm{D}}-\frac{5.16}{\mathrm{Re}} \log \left(\frac{\varepsilon}{3.7 \mathrm{D}}+\frac{5.09}{\mathrm{Re}^{0.87}}\right)\right]$ & Not specified & (17) \\
\hline
\end{tabular}


Continued from Table 1

\begin{tabular}{|c|c|c|c|}
\hline Authors (Year) & Explicit equation of the $f$ & Applicable ranges & $\begin{array}{l}\text { Equation } \\
\text { number }\end{array}$ \\
\hline $\begin{array}{l}\text { Romeo et al. } \\
\text { (2002) }\end{array}$ & $\begin{array}{c}\frac{1}{\sqrt{\mathrm{f}}}=-2 \log \left\{\frac{\varepsilon}{3.7065 \mathrm{D}}\right. \\
-\frac{5.0272}{\operatorname{Re}} \log \left[\frac{\varepsilon}{3.827 \mathrm{D}}\right. \\
\left.\left.-\frac{4.567}{\operatorname{Re}} \log \left(\left(\frac{\varepsilon}{7.7918 \mathrm{D}}\right)^{0.9924}+\left(\frac{5.3326}{208.815+\mathrm{Re}}\right)^{0.9345}\right)\right]\right\}\end{array}$ & $\begin{array}{c}3 \times 10^{3} \leq R e \leq 1.5 \times 10^{8} \\
0 \leq \varepsilon / D \leq 5 \times 10^{-2}\end{array}$ & (18) \\
\hline $\begin{array}{l}\text { Sonnad \& Goudar } \\
\qquad(2006)\end{array}$ & $\begin{array}{l}\frac{1}{\sqrt{f}}=0.8686 \ln \left(\frac{0.4587 R e}{G \frac{G}{G+1}}\right) \\
G=0.124 \operatorname{Re} \frac{\varepsilon}{D}+\ln (0.4587 R e)\end{array}$ & $\begin{array}{l}4 \times 10^{3} \leq R e \leq 10^{8} \\
10^{-6} \leq \varepsilon / D \leq 5 \times 10^{-2}\end{array}$ & (19) \\
\hline $\begin{array}{l}\text { Rao \& Kumar } \\
\quad(2007)\end{array}$ & $\begin{array}{c}\frac{1}{\sqrt{\mathrm{f}}}=2 \log \left[\frac{\left(2 \frac{\varepsilon}{\mathrm{D}}\right)^{-1}}{\left(\frac{0.444+0.135 \mathrm{Re}}{\operatorname{Re}}\right) \beta}\right] \\
\beta=1-0.55 \mathrm{e}^{-0.33\left[\ln \left(\frac{\mathrm{Re}}{6.5}\right)\right]^{2}}\end{array}$ & Not specified & (20) \\
\hline Buzzelli (2008) & $\begin{array}{c}\frac{1}{\sqrt{\mathrm{f}}}=\mathrm{B}_{1}-\left[\frac{\mathrm{B}_{1}+2 \log \left(\frac{\mathrm{B}_{2}}{\mathrm{Re}}\right)}{1+\frac{2.18}{\mathrm{~B}_{2}}}\right] \\
\mathrm{B}_{1}=\frac{[0.774 \ln (\mathrm{Re})]-1.41}{\left(1+1.32 \sqrt{\frac{\varepsilon}{\mathrm{D}}}\right)} \\
\mathrm{B}_{2}=\frac{\varepsilon}{3.7 \mathrm{D}} \operatorname{Re}+2.51 \mathrm{~B}_{1}\end{array}$ & $\begin{array}{c}3 \times 10^{3} \leq R e \leq 1.5 \times 10^{8} \\
0 \leq \varepsilon / D \leq 5 \times 10^{-2}\end{array}$ & (21) \\
\hline $\begin{array}{l}\text { Vantankhah \& } \\
\text { Kouchakzadeh } \\
\quad(2008)\end{array}$ & $\begin{aligned} \frac{1}{\sqrt{\mathrm{f}}} & =0.8686 \ln \left[\frac{0.4587 \mathrm{Re}}{(\mathrm{S}-0.31)^{\left(\frac{\mathrm{S}+0.9633}{)}\right)}}\right] \\
\mathrm{S} & =0.124 \operatorname{Re}\left(\frac{\varepsilon}{\mathrm{D}}\right)+\ln (0.4587 \mathrm{Re})\end{aligned}$ & $\begin{array}{l}4 \times 10^{3} \leq R e \leq 10^{8} \\
10^{-6} \leq \varepsilon / D \leq 5 \times 10^{-2}\end{array}$ & (22) \\
\hline $\begin{array}{l}\text { Avci \& Karagoz } \\
\quad(2009)\end{array}$ & $\mathrm{f}=\frac{6.4}{\left\{\ln (\operatorname{Re})-\ln \left[1+0.01 \operatorname{Re} \frac{\varepsilon}{\mathrm{D}}\left(1+10 \sqrt{\frac{\varepsilon}{\mathrm{D}}}\right)\right]\right\}^{2.4}}$ & Not specified & (23) \\
\hline $\begin{array}{l}\text { Papaevangelou et } \\
\text { al. }(2010)\end{array}$ & $\mathrm{f}=\frac{0.2479-0.0000947(7-\log \mathrm{Re})^{4}}{\left[\log \left(\frac{\varepsilon}{3.615 \mathrm{D}}+\frac{7.366}{\mathrm{Re}^{0.9142}}\right)\right]^{2}}$ & $\begin{aligned} 10^{4} & \leq R e \leq 10^{7} \\
10^{-5} & \leq \varepsilon / D \leq 10^{-3}\end{aligned}$ & (24) \\
\hline Brkić (2011a) & $\begin{array}{l}\frac{1}{\sqrt{f}}=-2 \log \left(\frac{2.18 \beta}{\operatorname{Re}}+\frac{\varepsilon}{3.71 \mathrm{D}}\right) \\
\beta=\ln \frac{\operatorname{Re}}{1.816 \ln \left[\frac{1.1 \mathrm{Re}}{\ln (1+1.1 \mathrm{Re})}\right]}\end{array}$ & Not specified & (25) \\
\hline Fang et al. (2011) & $\mathrm{f}=1.613\left\{\ln \left[0.234\left(\frac{\varepsilon}{\mathrm{D}}\right)^{1.1007}-\frac{60.525}{\mathrm{Re}^{1.1105}}+\frac{56.291}{\mathrm{Re}^{1.0712}}\right]\right\}^{-2}$ & $\begin{array}{l}3 \times 10^{3} \leq R e \leq 10^{8} \\
0 \leq \varepsilon / D \leq 5 \times 10^{-2}\end{array}$ & (26) \\
\hline $\begin{array}{l}\text { Ghanbari et al. } \\
\qquad(2011)\end{array}$ & $\mathrm{f}=\left\{-1.52 \log \left[\left(\frac{\varepsilon}{7.21 \mathrm{D}}\right)^{1.042}+\left(\frac{2.731}{\operatorname{Re}}\right)^{0.9152}\right]\right\}^{-2.169}$ & $\begin{aligned} 2.1 \times 10^{3} & \leq \mathrm{Re} \leq 10^{8} \\
0 & \leq \varepsilon / D \leq 5 \times 10^{-2}\end{aligned}$ & (27) \\
\hline $\begin{array}{l}\text { Shaikh et al. } \\
\text { (2015) }\end{array}$ & $\begin{array}{c}\mathrm{f}=0.25\left[\log \left(\frac{2.51}{\alpha \operatorname{Re}}+\frac{\varepsilon}{3.7 \mathrm{D}}\right)\right]^{-2} \\
\alpha=\left[1.14-2 \log \left(\frac{\varepsilon}{\mathrm{D}}\right)\right]^{-2}\end{array}$ & $\begin{array}{l}10^{4} \leq \operatorname{Re} \leq 10^{8} \\
10^{-4} \leq \varepsilon / D \leq 5 \times 10^{-2}\end{array}$ & (28) \\
\hline Brkić (2016) & $\frac{1}{\sqrt{f}}=-2 \log \left[\frac{2.51\left(1.14-2 \log \left(\frac{\varepsilon}{D}\right)\right)}{\operatorname{Re}}+\frac{\varepsilon}{3.71 D}\right]$ & $\begin{aligned} 10^{6} & <\operatorname{Re}<10^{8} \\
10^{-2} & <\varepsilon / D<5 \times 10^{-2}\end{aligned}$ & (29) \\
\hline $\begin{array}{l}\text { Offor \& Alabi } \\
\quad(2016)\end{array}$ & $\frac{1}{\sqrt{\mathrm{f}}}=-2 \log \left\{\frac{\varepsilon}{3.71 \mathrm{D}}-\frac{1.975}{\operatorname{Re}}\left[\ln \left(\left(\frac{\varepsilon}{3.93 \mathrm{D}}\right)^{1.092}+\left(\frac{7.627}{\operatorname{Re}+395.9}\right)\right)\right]\right\}$ & $\begin{array}{l}4 \times 10^{3} \leq R e \leq 10^{8} \\
0 \leq \varepsilon / D \leq 5 \times 10^{-2}\end{array}$ & (30) \\
\hline
\end{tabular}

where:

f - is the coefficient of head loss of the Darcy-Weisbach formulation (dimensionless);

$\varepsilon / D$ - is the relative roughness of the pipe (m); and

$\operatorname{Re} \quad$ - is the Reynolds number (dimensionless).

In all twenty nine explicit equations of the from different authors were analysed, years of publication, and range of applicability involving Re and $\varepsilon / D$, as listed in Table 1 . Their choice was determined to evaluate most of the equations available in the literature. In this study, any model devoid of iterations was considered explicit.

The precision, related to the distance of the values of the explicit equations in relation to $\mathrm{CW}$, was determined by the concordance index (d) proposed by Willmott (1981). The values ranged from 0 (without a match) to 1 (perfect match).

The Pearson correlation coefficient (r) allows quantifying the degree of association between the two variables involved 
in the analysis. The closer to 1 , the greater the degree of linear statistical dependence between the variables, and the closer to zero, the lower the strength of that relationship.

The equations were evaluated using the performance index (Id) adapted from Camargo \& Sentelhas (1997), whose value is the product of $\mathrm{d}$ and $\mathrm{r}$. The criteria for interpreting $\mathrm{d}, \mathrm{r}, \mathrm{Id}$, and their respective classifications are presented in Table 2.

After sorting the equations that had a performance index rated as "Excellent," the mean of the relative error (MRE) was calculated. According to Sadeghi et al. (2015), it is a very useful parameter for evaluating practically the most precise model for the estimation of the $f$.

The values of the MRE were classified as follows: "Very good," MRE $\leq$ 0.55; "Good," $0.55<$ MRE $\leq 1.00$; "Average," $1.00<\mathrm{MRE} \leq 2.00$; "Weak," $2.00<\mathrm{MRE} \leq 3.00$; and "Poor," $\mathrm{MRE}>3.00$.

Table 2. Criteria for interpreting the concordance index, the precision index, the performance index, and their respective classifications

\begin{tabular}{|c|c|c|c|}
\hline $\begin{array}{l}\text { Concordance } \\
\text { index (d) }\end{array}$ & $\begin{array}{c}\text { Correlation } \\
\text { coefficient (r) }\end{array}$ & $\begin{array}{c}\text { Performance } \\
\text { index (Id) }\end{array}$ & Classification \\
\hline $0.95-1.00$ & $0.95-1.00$ & $0.90-1.00$ & Excellent \\
\hline $0.89-0.95$ & $0.89-0.95$ & $0.80-0.90$ & Optimum \\
\hline $0.84-0.89$ & $0.84-0.89$ & $0.70-0.80$ & Very Good \\
\hline $0.77-0.84$ & $0.77-0.84$ & $0.60-0.70$ & Good \\
\hline $0.71-0.77$ & $0.71-0.77$ & $0.50-0.60$ & Moderately Good \\
\hline $0.63-0.71$ & $0.63-0.71$ & $0.40-0.50$ & Moderate \\
\hline $0.55-0.63$ & $0.55-0.63$ & $0.30-0.40$ & Moderately Poor \\
\hline $0.45-0.55$ & $0.45-0.55$ & $0.20-0.30$ & Poor \\
\hline $0.32-0.45$ & $0.32-0.45$ & $0.10-0.20$ & Very Poor \\
\hline $0.00-0.32$ & $0.00-0.32$ & $0.00-0.10$ & $\mathrm{Bad}$ \\
\hline
\end{tabular}

\section{Results AND Discussion}

All the explicit equations in relation to the CW standard presented d values very close to 1.00 , being classified as "Excellent," thus possessing a high degree of accuracy among the variables involved.

The $r$ of most of the explicit equations also provided values very close to 1.00 , demonstrating a good association of the variables involved. Eqs. 14, 25, 27, and 28 were classified as "Excellent," but had correlation coefficient (r) of less than 0.99 . Meanwhile, Eq. 20 had a lower value, with $r=0.93478$, being classified as "Optimum," and presented a lower correlation between the variables involved.

According to the Id, all the equations presented an "Excellent" classification, with values close to 1.00 except for Eq. 20, which obtained an Id of 0.93444 .

Analyzing the performance coefficients, we can conclude that all explicit equations obtained a satisfactory performance for the estimation of the $f$ when compared with the implicit $\mathrm{CW}$ formulation. Because of this, a statistical analysis was performed using the relative error (RE) to evaluate the most accurate model for estimating the $f$.

The approximations of Eqs. 8, 10, 12, 17, 19, 21, 22, 24, 26, and 30 presented an MRE lower than $0.55 \%$, all being classified as "Very good." The lowest value found was that of Eq. 30, with $\mathrm{MRE}=0.30 \%$.

Models 2, 3, 5, 9, 14, 23, 27, 29, 28, and 20 presented an MRE above $1.00 \%$, with the last two standing out owing to their higher MRE of 10.24 and $16.15 \%$, respectively. The other equations were classified as "Good."

The mean values of the RE found in this study are in agreement with those of Brkić (2011b), who carried out a review of 26 explicit approximations based on the RE criterion and concluded that most of the explicit models available are very precise, with the exception of those of Moody (1947), Wood (1966), Eck (1973), Round (1980), and Rao \& Kumar (2007).

According to Winning \& Coole (2013), when 28 explicit equations of the $\mathrm{f}$ were compared with $\mathrm{CW}$, the most precise approximations were those obtained by the equations of Zigrang \& Sylvester (1982), Romeo et al. (2002), and Buzzelli (2008). This study found similar values of accuracy, with the exception of Romeo et al. (2002), which presented higher values of RE.

Brkić (2011a), Winning \& Coole (2013) and Offor \& Alabi (2016) analyzing explicit equations of the $f$, found that the RE values of Rao \& Kumar's (2007) equation were the highest in relation to all the explicit equations analyzed in their research, being consistent with what was obtained in this study.

The discrepancy between the RE values found in this study and those obtained by Brkić's (2016) proposed equation is possibly due to the fact that the approximation obtained by this study covers a limited range of applicability of Re and $\varepsilon / D$, with values of $10^{6}<\operatorname{Re}<10^{8}$ and $10^{-2}<\varepsilon / D<5 \times 10^{-2}$ only, respectively.

For an approximation of the range of applicability that the CW equation provides, only the explicit equations covering $4 \times 10^{3} \leq \mathrm{Re} \leq 10^{8}$ and $10^{-6} \leq \mathrm{E} / \mathrm{D} \leq 5 \times 10^{-2}$ and $\mathrm{MRE}<0.55 \%$ will be valid. This is applied because some highly accurate approximations are valid only at limited Re and $\varepsilon / D$ intervals and, thus, may incorrectly estimate the $f$.

Of the 29 explicit approximations of the f analyzed, only 7 satisfied these conditions, which were Eqs. 8, 10, 19, 21, 22, 26, and 30. These approximations are presented in Figure 1A-G, which shows the RE distribution for the entire Re range of $4 \times 10^{3} \leq \operatorname{Re} \leq 10^{8}$ and the $\mathrm{E} / \mathrm{D}$ of $10^{-6} \leq \mathrm{E} / \mathrm{D} \leq 5 \times 10^{-2}$.

A joint analysis of Figure $1 \mathrm{~A}-\mathrm{G}$ shows that the equation of Sonnad \& Goudar (2006) presented the highest value of the maximum RE and the lowest value of the minimum RE in relation to the others, with values of 3.17 and $0.003 \%$, respectively.

For Chen (1979), the minimum RE value was $0.019 \%$ for an $\varepsilon / \mathrm{D}$ of $10^{-5}$ and an Re of $5 \times 10^{6}$, and the maximum $\mathrm{RE}$ value was $1.837 \%$ for an $\mathcal{E} / \mathrm{D}$ of $10^{-4}$ and an Re of $4 \times 10^{3}$. Shacham (1980) presented a minimum $\mathrm{RE}$ value of $0.069 \%$ for an $\varepsilon / D$ of $5 \times 10^{-6}$ and an $\operatorname{Re}$ of $5 \times 10^{7}$, and a maximum $\mathrm{RE}$ value of $1.270 \%$ for an $E / D$ of $10^{-6}$ and an Re of $4 \times 10^{3}$.

For Buzzelli (2008), the minimum RE value was $0.007 \%$ for an $\varepsilon / D$ of $5 \times 10^{-6}$ and an $\operatorname{Re}$ of $5 \times 10^{7}$, and the maximum RE value was $2.156 \%$ for an $E / D$ of $10^{-6}$ and an Re of $4 \times 10^{3}$. Vantankhah \& Kouchakzadeh (2008) presented a minimum RE value of $0.01 \%$ for an $\varepsilon / D$ of $5 \times 10^{-6}$ and an Re of $5 \times 10^{7}$, and a maximum $\mathrm{RE}$ value of $2.112 \%$ for an $\varepsilon / \mathrm{D}$ of $10^{-6}$ and an Re of $4 \times 10^{3}$.

Fang et al. (2011) presented a minimum RE value of $0.009 \%$ for an $\varepsilon / D$ of $2 \times 10^{-3}$ and an Re for $10^{5}$, and a maximum RE 
A.

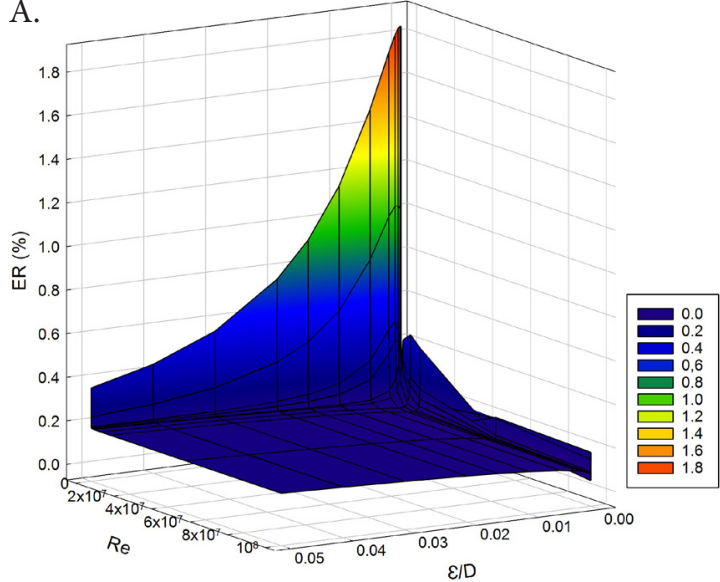

C.

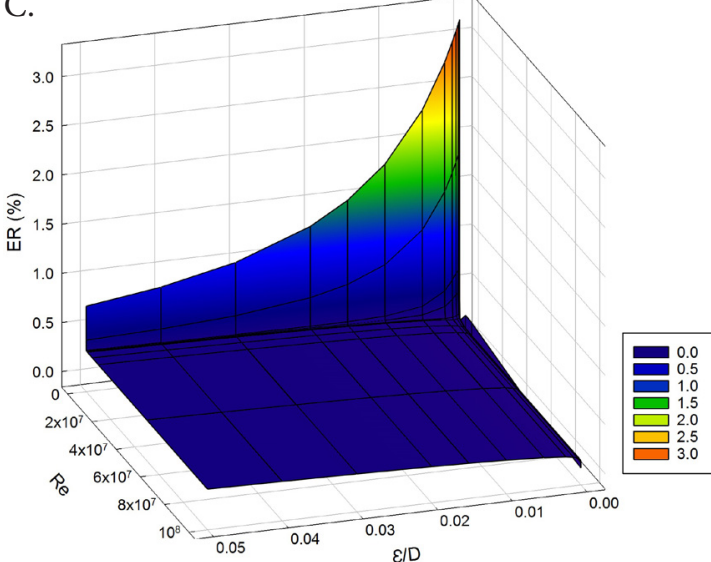

E.

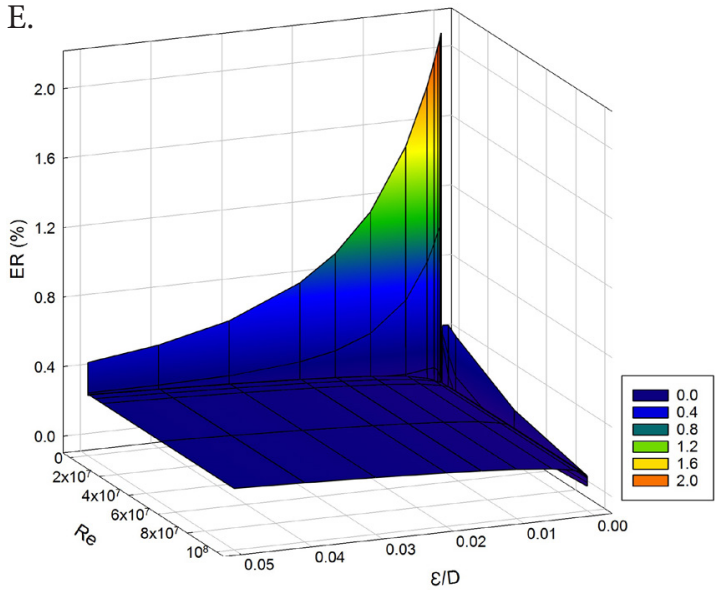

B.

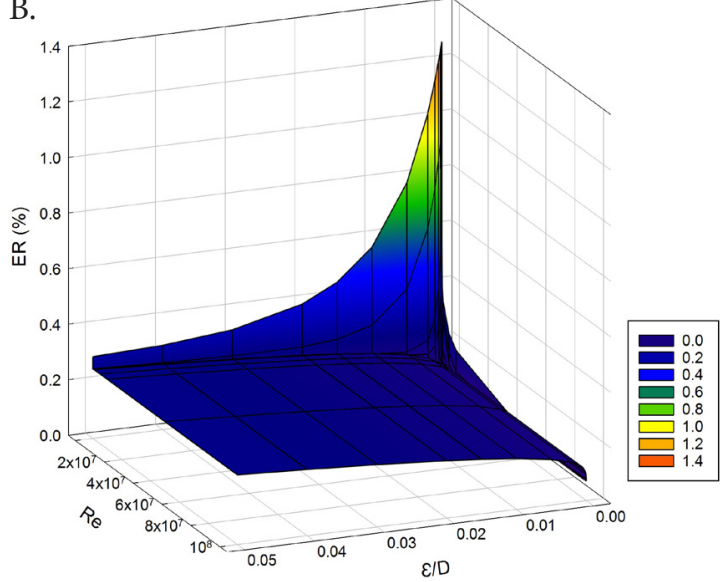

D.

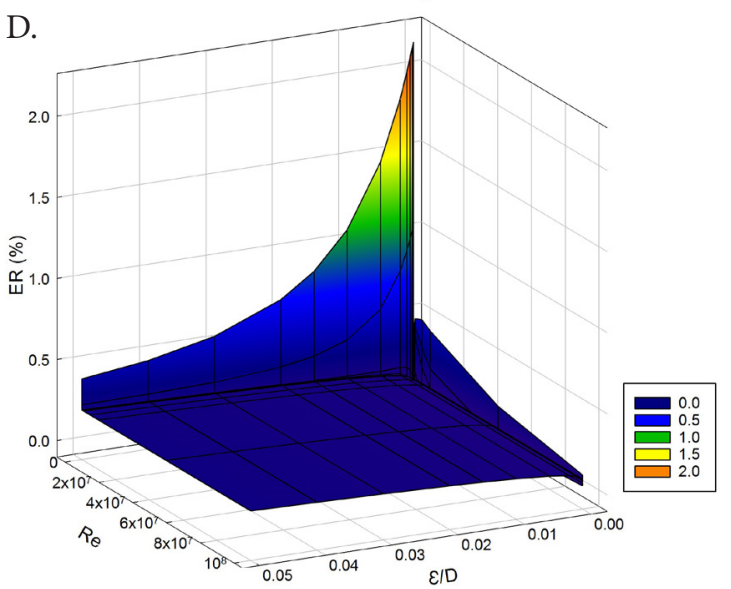

F.

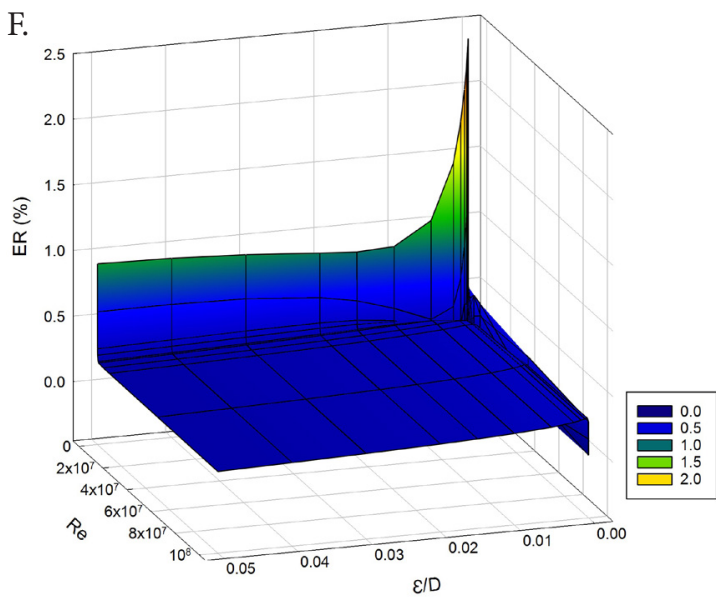

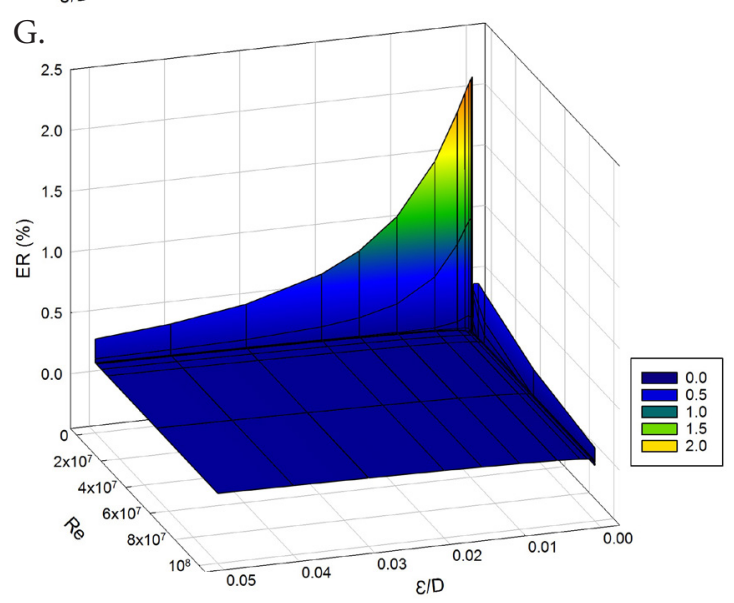

Figure 1. Distribution of the relative error estimate (RE\%), Reynolds number (Re), and relative roughness (E/D) produced by the equations of A) Chen (1979); B) Shacham (1980); C) Sonnad \& Goudar (2006); D) Buzzelli (2008); E) Vantankhah \& Kouchakzadeh (2008); F) Fang et al. (2011), and G) Offor \& Alabi (2016), when compared to the Colebrook-White (1937) equation (Eq. 1) 
value of $2.375 \%$ for an $E / D$ of $10^{-6}$ and an $\operatorname{Re}$ of $4 \times 10^{3}$. For Offor \& Alabi (2016), the minimum value of RE was $0.005 \%$ for an $\varepsilon / D$ of $5 \times 10^{-6}$ and an Re of $10^{8}$, and the maximum RE value was $2.128 \%$ for an $E / D$ of $5 \times 10^{-6}$ and an Re of $4 \times 10^{3}$.

\section{Conclusions}

1. The equations of Chen (1979), Shacham (1980), Sonnad \& Goudar (2006), Buzzelli (2008), Vantankhah \& Kouchakzadeh (2008), Fang et al. (2011), and Offor \& Alabi (2016) showed higher performance indexes and precision when compared to the Colebrook-White approximation.

2. The equation of Offor \& Alabi (2016), in relation to the explicit models analyzed, stood out from the others, presenting the highest performance index and precision, apart from covering the widest range of Reynolds number applicability and showing the highest relative roughness, and, therefore, can be used as an alternative to the implicit Colebrook-White equation.

\section{Literature Cited}

Assefa, K. M.; Kaushal, D. R. A comparative study of friction factor correlations for high concentrate slurry flow in smooth pipes. Journal of Hydrology and Hydromechanics, v.63, p.13-20, 2015. https://doi.org/10.1515/johh-2015-0008

Avci, A.; Karagoz, I. A novel explicit equation for friction factor in smooth and rough pipes. Journal of Fluids Engineering, v.131, p.1-2, 2009. https://doi.org/10.1115/1.3129132

Bardestani, S.; Givehchi, M.; Younesi, E.; Sajjadi, S.; Shamshirband, S.; Petkovic, D. Predicting turbulent flow friction coefficient using ANFIS technique. Signal, Image and Video Processing, v.11, p.341-347, 2017. https://doi.org/10.1007/s11760-016-0948-8

Barr, D. I. H. Solutions of the Colebrook-White function for resistance to uniform turbulent flow. Proceedings of the Institution of Civil Engineers, v.71, p.529-536, 1981.

Brkić, D. New explicit correlations for turbulent flow friction factor. Nuclear Engineering and Design, v.241, p.4055-4059, 2011a. https://doi.org/10.1016/j.nucengdes.2011.07.042

Brkić, D. Review of explicit approximations to the Colebrook relation for flow friction. Journal of Petroleum Science and Engineering, v.77, p.34-48, 2011b. https://doi.org/10.1016/j.petrol.2011.02.006

Brkić, D. A note on explicit approximations to Colebrook's friction factor in rough pipes under highly turbulent cases. International Journal of Heat and Mass Transfer, v.93, p.513-515, 2016. https:// doi.org/10.1016/j.ijheatmasstransfer.2015.08.109

Brkić, D.; Ćojbašić, Ž. Intelligent flow friction estimation. Computational Intelligence and Neuroscience, v.2016, p.1-10, 2016. https://doi.org/10.1155/2016/5242596

Brkić, D.; Ćojbašić, Ž. Evolutionary optimization of Colebrook's turbulent flow friction approximations. Fluids, v.2, p.1-27, 2017. https://doi.org/10.3390/fluids2020015

Buzzelli, D. Calculating friction in one step. Machine Design, v.80, p.54-55, 2008.

Camargo, A. P.; Sentelhas, P. C. Avaliação do desempenho de diferentes métodos de estimativa da evapotranspiração potencial no estado de São Paulo, Brasil. Revista Brasileira de Agrometeorologia, v.5, p.89-97, 1997.
Chen, N. H. An explicit equation for friction factor in pipes. Industrial \& Engineering Chemistry Fundamentals, v.18, p.296-297, 1979. https://doi.org/10.1021/i160071a019

Churchill, S. W. Empirical expressions for the shear stress in turbulent flow in commercial pipe. AIChE Journal, v.19, p.375-376, 1973. https://doi.org/10.1002/aic.690190228

Çoban, M. T. Error analysis of non-iterative friction factor formulas relative to Colebrook-White equation for the calculation of pressure drop in pipes. Journal of Naval Science and Engineering, v.8, p.1-13, 2012.

Colebrook, C. F.; White, C. M. Experiments with fluid friction in roughened pipes. Proceedings of the Royal Society A: Mathematical, Physical and Engineering Sciences, v.161, p.367381, 1937. https://doi.org/10.1098/rspa.1937.0150

Eck, B. Technische Stromungslehre. New York: Springer, 1973. 324p.

Fang, X.; Xu, Y.; Zhou, Z. New correlations of single-phase friction factor for turbulent pipe flow and evaluation of existing singlephase friction factor correlations. Nuclear Engineering and Design, v.241, p.897-902, 2011. https://doi.org/10.1016/j. nucengdes.2010.12.019

Ghanbari, A.; Farshad, F.; Rieke, H. Newly developed friction factor correlation for pipe flow and flow assurance. Journal of Chemical Engineering and Materials Science, v.2, p.83-86, 2011.

Haaland, S. E. Simple and explicit formulas for friction factor in turbulent pipe flow. Journal of Fluids Engineering, v.105, p.89-90, 1983. https://doi.org/10.1115/1.3240948

Heydari, A.; Narimani, E.; Pakniya, F. Explicit determinations of the Colebrook equation for the flow friction factor by statistical analysis. Chemical Engineering \& Technology, v.38, p.1387-1396, 2015. https://doi.org/10.1002/ceat.201400590

Jain, A. K. Accurate explicit equation for friction factor. Journal of the Hydraulics Division, v.102, p.674-677, 1976.

Manadilli, G. Replace implicit equations with signomial functions. Chemical Engineering, v.104, p.129-129, 1997.

Mikata, Y.; Walczak, W. S. Exact analytical solutions of the ColebrookWhite equation. Journal of Hydraulic Engineering, v.142, p.1-6, 2015

Moody, L. F. Friction factors for pipe flow. Transactions ASME, v.66, p.671-678, 1944.

Moody, L. F. An approximate formula for pipe friction factors. Transactions ASME, v.69, p.1005-1011, 1947.

Offor, U. H.; Alabi, S. B. An accurate and computationally efficient friction factor model. Advances in Chemical Engineering and Science, v.6, p.237-245, 2016. https://doi.org/10.4236/ aces.2016.63024

Papaevangelou, G.; Evangelides, C.; Tzimopoulos, C. A new explicit equation for the friction coefficient in the Darcy-Weisbach equation. In: Proceedings of the Tenth Conference on Protection and Restoration of the Environment, v.166, p.6-9, 2010.

Rao, A. R.; Kumar, B. Friction factor for turbulent pipe flow. Bangalore: Division of Mechanical Science, Civil Engineering Indian Institute of Science Bangalore, 2007. 16p.

Robaina, D. A. Análise de equações explícitas para o cálculo do coeficiente " $\mathrm{f}$ " da fórmula universal de perda de carga. Ciência Rural, v.22, p.157-159, 1992. https://doi.org/10.1590/S010384781992000200006 
Romeo, E.; Royo, C.; Monzón, A. Improved explicit equation for estimation of the friction factor in rough and smooth pipes. Chemical Engineering Journal, v.86, p.369-374, 2002. https://doi. org/10.1016/S1385-8947(01)00254-6

Round, G. F. An explicit approximation for the friction factorReynolds number relation for rough and smooth pipes. The Canadian Journal of Chemical Engineering, v.58, p.122-123, 1980. https://doi.org/10.1002/cjce.5450580119

Sadeghi, S.; Peters, R. T.; Lamm, F. R. Design of zero slope microirrigation laterals: Effect of the friction factor variation. Journal of Irrigation and Drainage Engineering, v.141, p.1-9, 2015. https://doi. org/10.1061/(ASCE)IR.1943-4774.0000905

Shacham, M. Comment on "Explicit equation for friction factor in pipe". Industrial \& Engineering Chemistry Fundamentals, v.19, p.228-229, 1980. https://doi.org/10.1021/i160074a019

Shaikh, M. M.; Massan S. ur R.; Wagan, A. I. A new explicit approximation to Colebrook's friction factor in rough pipes under highly turbulent cases. International Journal of Heat and Mass Transfer, v.88, p.538-543, 2015. https://doi.org/10.1016/j. ijheatmasstransfer.2015.05.006

Sonnad, J. R.; Goudar, C. T. Turbulent flow friction factor calculation using a mathematically exact alternative to the Colebrook-White equation. Journal of Hydraulic Engineering, v.132, p.863-867, 2006. https://doi.org/10.1061/(ASCE)0733-9429(2006)132:8(863)
Sousa, J.; Cunha, M. da C.; Marques, A. S. An explicit solution of the Colebrook-White equation through simulated annealing. Water Industry Systems: Modelling and Optimization Applications, v.2, p.347-355, 1999.

Swamee, P. K.; Jain, A. K. Explicit equations for pipe flow problems. Journal of the Hydraulics Division, v.102, p.657-664, 1976.

Tsal, R. J. Altshul-Tsal friction factor equation. Heating, Piping and Air Conditioning, v.8, p.30-45, 1989.

Vatankhah, A. R.; Kouchakzadeh, S. Discussion of "Turbulent flow friction factor calculation using a mathematically exact alternative to the Colebrook-White equation" by Jagadeesh R. Sonnad and Chetan T. Goudar. Journal Hydraulic Engineering, v.134, p.1-9, 2008. https://doi.org/10.1061/(ASCE)07339429(2008)134:8(1187)

Willmott, C. J. On the validation of models. Physical Geography, v.2, p.184-194, 1981.

Winning, H. K.; Coole, T. Explicit friction factor accuracy and computational efficiency for turbulent flow in pipes. Flow, Turbulence and Combustion, v.90, p.1-27, 2013. https://doi. org/10.1007/s10494-012-9419-7

Wood, D. J. An explicit friction factor relationship. Civil Engineering, v.36, p.60-61, 1966.

Zigrang, D. J.; Sylvester, N. D. Explicit approximations to the solution of Colebrook's friction factor equation. AIChE Journal, v.28, p.514-515, 1982. https://doi.org/10.1002/aic.690280323 